\title{
Maprotiline treatment differentially influences cardiac $\beta$-adrenoreceptors expression under normal and stress conditions
}

\author{
Natasa Spasojevic*, Predrag Jovanovic, Sladjana Dronjak
}

Laboratory for Molecular Biology and Endocrinology, Institute of Nuclear Sciences “Vinca”, University of Belgrade, Serbia

\begin{abstract}
Alterations in cardiac function were observed in antidepressants treated patients and published in several clinical reports. These detected changes could be either a consequence of the treatment or of depression itself, which has already been proved to be a risk factor in heart diseases. In order to determine a possible influence of chronic treatment with norepinephrinergic reuptake inhibitor, maprotiline, on the heart, we investigated gene expression of cardiac $\beta$-adrenoceptors both in controls and in animals with signs of depression. The rats were divided into two groups, unstressed controls and those exposed to chronic unpredictable mild stress (CUMS). The groups were further divided into two subgroups, one receiving daily intraperitoneal injections of vehicle (sterile water) and another one maprotiline $(10 \mathrm{mg} / \mathrm{kg})$ for four weeks. Tissue samples were collected after the last application. Gene expression of cardiac $\beta_{1}$ - and $\beta_{2}$-adrenoceptor was determined using Real-time RT-PCR analysis. Our results show that in control animals expression of both adrenoreceptors was decreased in the right atria after 4 weeks of maprotiline application. Contrary, the same treatment led to a significant increase in expression of cardiac $\beta_{1^{-}}$ adrenoceptor in the stressed rats, with no change in the characteristics of $\beta_{2}$-adrenoceptor. Our findings might reflect the that molecular mechanisms are underlying factors involved in the development of cardiovascular diseases linked with antidepressant treatment.
\end{abstract}

Uniterms: Antidepressants. Depression/treatment. Cardiovascular diseases/associated with the use of antidepressants. $B$-adrenoceptors/gene expression.

Vários relatórios clínicos observaram alterações de funcionamento cardíaco de pacientes depressivos que foram tratados com os antidepressivos. As alterações detectadas podem ser consequência do tratamento ou, por outro lado, da depressão que, como se tem provado, é um fator de risco no caso de doenças cardíacas. De modo a determinar a possível influência de tratamento crônico com o inibidor da recaptação de norepinefrina, maprotilina, no coração, foi investigada a expressão do gene aos receptores $\beta$-adrenérgicos cardíacos dos animais em grupos de controle e em grupos com sinais de depressão. Os ratos foram divididos em grupos de controle não estressados e os grupos de ratos submetidos ao estresse crônico moderado imprevisível (CUMS). Os grupos foram, ainda, divididos em dois subgrupos, que, durante quatro semanas, diariamente receberam injeções intraperitoneais de placebo (água estéril) ou de maprotilina $(10 \mathrm{mg} / \mathrm{kg})$. As amostras de tecido foram coletadas após a última aplicação. A expressão do gene aos receptores adrenérgicos $\beta 1$ e $\beta 2$ foi determinada utilizando a análise PCR quantitativa em tempo real (RT-PCR). Os nossos resultados demonstram a diminuição de expressão dos ambos os receptores adrenérgicos no átrio direito dos animais do grupo de controle depois de quatro semanas de aplicação de maprotilina. Em contraste, o mesmo tratamento conduziu ao aumento significativo na expressão do receptor $\beta 1$-adrenérgico no coração dos ratos estressados, sem qualquer alteração nas características do receptor $\beta 2$-adrenérgico. Estes resultados podem refletir os mecanismos moleculares envolvidos no desenvolvimento de doenças cardiovasculares associadas ao tratamento com os antidepressivos.

Unitermos: Antidepressivos. Depressão/tratamento. Doenças cardiovasculares/associação ao uso de antidepressivos. Receptores ß-adrenérgicos cardíacos/expressão do gene.

\footnotetext{
*Correspondence: Natasa Spasojevic. Laboratory for Molecular Biology and
} Endocrinology, Institute of Nuclear Sciences "Vinca", University of Belgrade, P.O.B. 522-090, 11000 Belgrade, Serbia. E-mail: snatally@vinca.rs 


\section{INTRODUCTION}

Depression is associated with the autonomic nervous system dysfunction that could have a negative impact on cardiovascular function (Carney et al., 2005). Several studies have demonstrated an exaggerated norepinephrine response in major depression (Lake et al., 1982; Veith et al., 1994; Yehuda et al., 1998; Mausbach et al., 2005). Chronic exposure to elevated levels of catecholamines, released from sympathetic nerve terminals and the adrenal gland, may cause pathologic changes, resulting in alterations in cardiac structure and function (Brum et al., 2002, Lohse et al., 2003). Activation of the closely related $\beta_{1}$ - and $\beta_{2}$-adrenergic receptors $\left(\beta_{1}\right.$-AR and $\beta_{2}$-AR) by released catecholamines is the primary trigger of molecular changes in the heart. These two subtypes are expressed in cardiac tissue at a ratio of 70:30, and their activation lead to an increase in contractile force and heart rate (Wallukat, 2002). The ratio of $\beta_{1}$-AR to $\beta_{2}$-AR subtypes depends on the type of animals and it is modified in pathological conditions (Brodd, Michel, 1999). Both receptors are highly homologous and activate the $\mathrm{G}$ protein stimulatory for adenylyl cyclase (Gs),yet they have distinguishable biological effects (Xiang, Kobilka, 2003). Thus, the $\beta_{1^{-}}$ AR plays the dominant role in stimulating heart rate and strength of myocyte contraction, whereas $\beta_{2}$-AR produces only modest chronotropic effects. Furthermore, chronic stimulation of $\beta_{1}$-AR produces myocyte hypertrophy and apoptosis, whereas $\beta_{2}$-AR signaling promotes cell survival (Xiao et al., 2004).

Stress is a key etiological factor in anxiety and major depressive disorders (Caspi et al., 2003). The chronic unpredictable mild stress (CUMS) procedure is an animal model that mimics the role of chronic stress in precipitating depression and induces various long-term physical, behavioural, neurochemical and neuroendocrine alterations that resemble those observed in depressed patients, which are reversed only by chronic antidepressants treatments (Wilner et al., 1992; Mineur et al., 2006; Yalcin et al., 2007). Maprotiline is a antidepressant with an atypical tetracyclic structure, which function is to prevent reuptake by blocking norepinephrine transporter. It is commonly used in elderly patients suffering from depression as longterm medication (Ahles et al., 1984). In the past, there have been only several clinical reports on the rise in heart rate (Hewer et al., 1995) and proarrhythmia (Lentini et al., 2001; Zuchner, 2002) linked to maprotiline.

This raises a question of a possible influence of maprotiline on $\beta$-adrenergic receptors gene expression in the heart of these animals. Applying TaqMan RT-PCR we have estimated the influence of long-term treatment with norepinephrinergic reuptake inhibitor, maprotiline, on gene expression of $\beta_{1}$ and $\beta_{2}$ adrenoreceptors, in the right and left atria as well as in the ventricle of unstressed controls and rats exposed to CUMS for 4 weeks.

\section{MATHERIAL AND METHODS}

\section{Animals and study design}

Adult Wistar rat males weighing 280-320 g at the onset of experiments and maintained in a temperature-controlled room $\left(21 \pm 1.0^{\circ} \mathrm{C}\right)$ and $12 \mathrm{~h} / 12 \mathrm{~h}$ light/dark cycle, were used. Care was taken to minimise the pain and discomfort of the animals in accordance with the Guide for Care and Use of Laboratory Animals of the National Institute of Health, Bethesda, MD, U.S.A. Research investigations were approved by Ethical Committee of the "Vinca" Institute, Belgrade (Application No. 02/11). The rats were randomly divided into control (unstressed) and group subjected to CUMS according to the method by Grippo et al. (2006). These two groups were further divided into two subgroups each, and the animals were receiving daily injections of vehicle (sterile water) or maprotiline $(10 \mathrm{mg} / \mathrm{kg})$ by i.p. route. Exposure to CUMS and the vehicle, i.e. drug administration started on the same day and were continued for 4 weeks. Maprotiline (Sigma-Aldrich Chemie, Germany) solutions in sterile water, sonicated for approximately $10 \mathrm{~min}$ were prepared ex tempore. Upon completion of 4 weeks, the animals exposed to CUMS and the corresponding controls were decapitated, the right and left cardiac atria and ventricles rapidly dissected, frozen in liquid nitrogen and stored at $-70{ }^{\circ} \mathrm{C}$ until analysed.

\section{RNA isolation and cDNA synthesis}

Total RNAs were isolated using TRIZOL reagent (Invitrogen, CA, U.S.A.). Reverse transcription was performed using Ready-To-Go You-Prime First- Strand Bead (AP, Biotech) and pd (N)6 primer according to manufacturer's protocol.

\section{Real-time RT-PCR}

TaqMan PCR assays were carried out using Assayon-Demand Gene Expression Products (Applied Biosystems, USA) for $\beta_{1}-\mathrm{AR}(\mathrm{Rn} 00824536$ s 1$)$ and $\beta_{2}-\mathrm{AR}(\mathrm{Rn}$ $\left.00560650 \_\mathrm{s} 1\right)$. The reactions were performed in a $25 \mu \mathrm{L}$ reaction mixture containing 1x TaqMan Universal Master Mix with AmpErase UNG, 1x Assay Mix (Applied Biosystems) and cDNA template (10 ng of RNA converted to 
cDNA). PCR reactions were performed in the ABI Prism 7000 Sequence Detection System at $50{ }^{\circ} \mathrm{C}$ for $2 \mathrm{~min}, 95$ ${ }^{\circ} \mathrm{C}$ for $10 \mathrm{~min}$, followed by 40 cycles at $95{ }^{\circ} \mathrm{C}$ for $15 \mathrm{~s}$ and $60{ }^{\circ} \mathrm{C}$ for $1 \mathrm{~min}$. A reference, endogenous control, was included in each analysis to correct the differences in the inter-assay amplification efficiency and all transcripts were normalised to cyclophyline A (ID:Rn 00690933) expression. Quantification was done using the $2^{-\Delta \Delta \mathrm{Ct}}$ method according to Livak and Schmittgen (2001).

\section{Statistical analysis}

The results are reported as means \pm S.E.M. Significance of the differences between the groups in gene expression levels of the examined $\beta$-AR were estimated by Two-way ANOVA test, followed by the Tukey post hoc test. Statistical significance was accepted at $\mathrm{p}<0.05$.

\section{RESULTS}

In our present study, we investigated the alterations in relative gene expression of $\beta_{1}$ - and $\beta_{2}$-AR in the right and left atria and ventricles after chronic maprotiline application in rats exposed to CUMS for 4 weeks in comparison with unstressed controls. Results indicate that stress procedure induced a considerable effect $\left(\mathrm{F}_{(1,20)}=17.87, \mathrm{p}<0.001\right)$ on $\beta_{1}$-AR gene expression in the left atria. Chronic stress increased $\beta_{1}$-AR mRNA levels by $75 \%(p<0.01)$ in the left atria. On the other hand, antidepressant treatment affected $\beta_{1}$-AR gene expression $\left(\mathrm{F}_{(1,20)}=45.21, \mathrm{p}<0.001\right)$ in the right atria. In addition, maprotiline effect on the unstressed animals was quite different from that on the stressed ones. Thus, this antidepressant led to an increase in $\beta_{1}$-AR mRNA levels by $224 \%(p<0.001)$ in the right atria of CUMS rats, but decreased it by $47 \%(\mathrm{p}<0.001)$ in controls. Analysis of data also displayed a significant interaction $\left(F_{(1,20)}=9.56, p<0.01\right)$ between effects of chronic stress and antidepressant treatment on $\beta_{1}$-AR mRNA levels in the left ventricle. In animals subjected to CUMS for 4 weeks and parallelly treated with maprotilin, $\beta_{1}$-AR mRNA levels were increased by $76 \%(\mathrm{p}<0.01)$ in the left ventricle (Fig. 1).

Two-way ANOVA test pointed to a significant difference in $\beta_{2}$-AR mRNA levels between unstressed and chronically stressed groups both in left atria $\left(\mathrm{F}_{(1,20)}=8.01\right.$, $\mathrm{p}<0.05)$ and in the left ventricle $\left(\mathrm{F}_{(1,20)}=43.52, \mathrm{p}<0.001\right)$. CUMS procedure increased $\beta_{2}$-AR mRNA levels in both left atria (by $34 \%, p<0.05$ ) and left ventricles (by $40 \%$, $\mathrm{p}<0.01)$. Maprotiline affected gene expression of $\beta_{2}$-AR $\left(\mathrm{F}_{(1,20)}=5.71, \mathrm{p}<0.05\right)$ in right atria. Antidepressant treat-

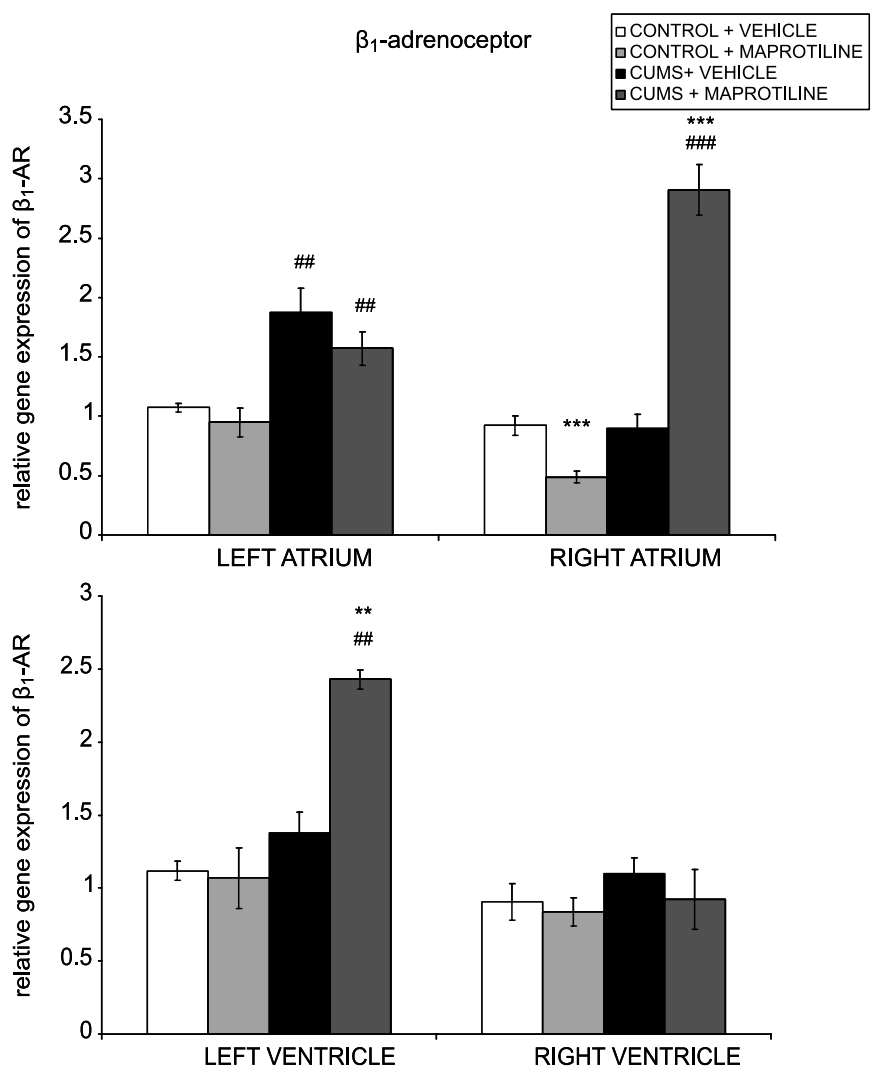

FIGURE 1 - The effects of chronic maprotiline treatment on $\beta_{1}$-adrenoceptors mRNA levels in left and right cardiac atrium and ventricle of unstressed and CUMS rats. The values are means \pm S.E.M. of 7 rats. Statistical significance: \#\# $\mathrm{p}<0.01$; \#\#\# p $<0.001$ CUMS vs. control (Tukey-test); ${ }^{* *} \mathrm{p}<0.01 ; * * * \mathrm{p}<$ 0.001 maprotiline vs. vehicle (Tukey-test). The final result was expressed as fold change relative to the calibrator and normalized to cyclophyline A.

ment decreased $\beta_{2}$-AR levels by $21 \%(p<0.05)$ in controls, but had no significant effect in stressed rats (Fig. 2).

\section{DISCUSSION}

Antidepressant prescriptions are often associated with an increased risk of heart disease (Rosenberg et al., 2010). Tata et al. (2005) reported that this risk is more likely associated to factors relating to depression itself than to specific adverse drug effects. Therefore, we examined whether the effect of maprotiline treatment on gene expression of $\beta_{1}$ and $\beta_{2}$-adrenoceptor in the heart of animals with depressive symptoms, which were induced by the 4 weeks exposure to CUMS, differed from that in unstressed rats. In control animals expression of both adrenoreceptors was decreased in right atria after four weeks of maprotiline application. Down-regulation of the $\beta$-adrenergic receptors appears to be a common effect of most tricyclic antidepres- 

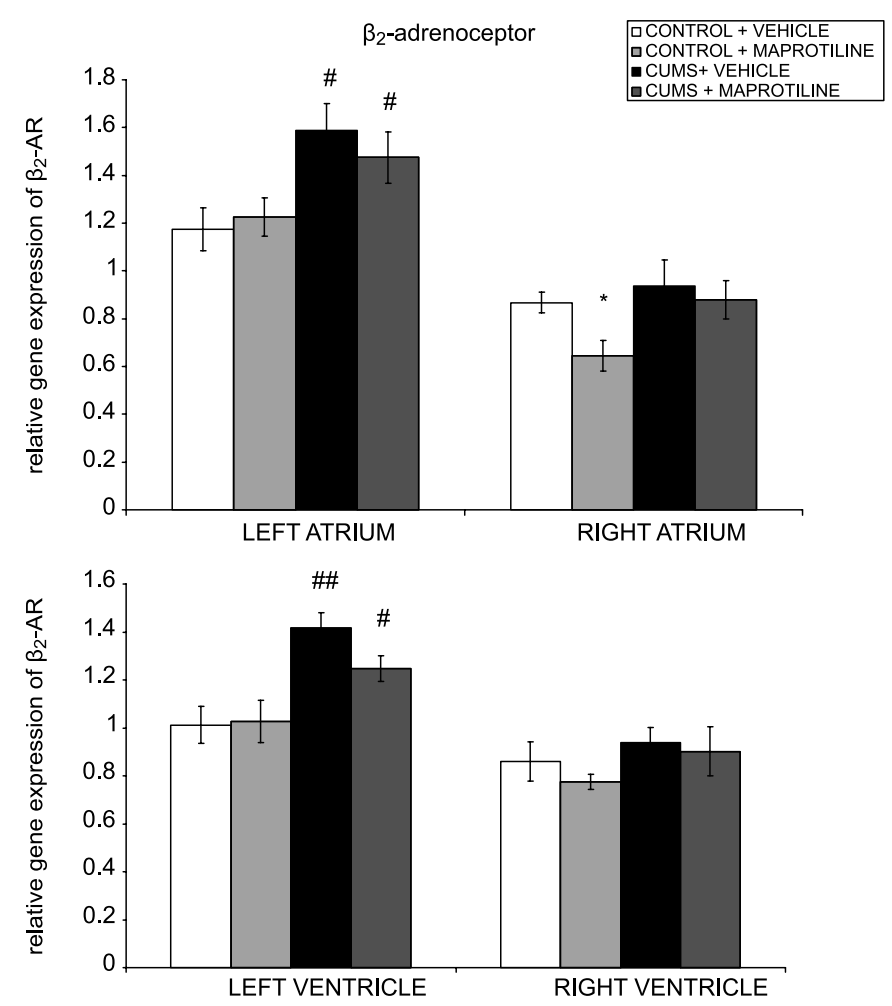

FIGURE 2 - The effects of chronic maprotiline treatment on $\beta_{2}-$ adrenoceptors mRNA levels in left and right cardiac atrium and ventricle of unstressed and CUMS rats. The values are means \pm S.E.M.of 7 rats. Statistical significance: \# $p<0.05$; \#\# $\mathrm{p}<0.01$ CUMS vs. control (Tukey-test); ${ }^{*} p<0.05$ maprotiline vs. vehicle (Tukey-test). The final result was expressed as fold change relative to the calibrator and normalized to cyclophyline A.

sants (Duman et al., 1997; Deupree et al., 2007). This may be related to adaptive processes regarded as a secondary effect to the increased concentration of norepinephrine in the synaptic cleft. Similarly, prolonged agonist exposure decreases both $\beta_{1}$-AR binding activity and $\beta_{1}$-AR mRNA levels (Dunigan et al., 2002). Port et al.(1992) identifed a $35 \mathrm{kDa} \beta$-AR mRNA-binding protein ( $\beta$-ARB protein) which is involved in agonist-induced destabilization of $\beta_{2}-$ AR mRNA. They have shown that the amount of $\beta$-ARB protein correlates inversely with the decrease in $\beta_{2}$-AR mRNA during the treatment with agonists in hamster heart cells. Antidepressants might also affect $\beta$-adrenergic receptors transcription that is independent of the inhibition of norepinephrine uptake. An intact $\mathrm{Sp} 1$ site is required for the full activity of the $\beta_{1}$-AR promoter in heart cells. The conservation of this binding site across mammalian $\beta_{1}$-AR genes suggests that this element is crucial for the $\beta_{1}$-AR gene expression regulation (Bahouth et al., 2002). It has been observed that chronic desipramine produced a significant reduction in Sp1-binding activity (Frechilla et al., 1998). In our experiments, as a result of exposure to
CUMS, a significant increase in $\beta_{1}$ - and $\beta_{2}$-adrenoceptor mRNA levels was recorded in left atria whereas $\beta_{2}$-ARs mRNA levels were increase only in left ventricles. According to Ueyama and colleagues (2003) activation of $\beta$-ARs is the primary trigger of emotional stress-induced molecular changes in the heart. Glucocorticoids are known to affect expression of these receptors through GRE sequences in promotor region (Malbon, Hadcock, 1988). In these animals, as previously shown, plasma corticosterone levels were elevated (Dronjak et al., 2007). Similarly, Misliveček et al. (2003) noticed that after hydrocortisone treatment density of both $\beta_{1}$-AR and $\beta_{2}$-AR was increased. In contrast to control group of animals, maprotiline treatment led to a significant increase in the expression of $\beta_{1}$ AR but remained without effect on $\beta_{2}$-AR expression in stressed rats. Chronic antidepressant treatment, which enhances norepinephrine synaptic transmission, was shown to increase phosphorylation of CREB and CRE-mediated gene expression in several brain regions (Thome et al., 2000; Abdel-Razaq et al., 2007). Tseng and co-workers (1998) demonstrated that cAMP mediates the induction of $\beta_{1}$-AR gene expression by interacting with CRE within the promoter region. It has been also observed that glucocorticoids, which are present during chronic stress, interacting with transcription factor CREB, can prevent downregulation of $\beta_{2}$-AR number and mRNA expression (Mak et al., 1995; Adcock et al., 1996). According to Dangel and co-workers (1996), glucocorticoids also induce changes in the $\beta_{2}$-AR RNA stability by reducing the amount of $\beta$-ARB protein. In addition, antidepressants could also regulate mRNA stability. The studies conducted by Headley and coworkers (2004) demonstrated that stimulation of mitogenactivated protein kinases-MAPKs (JNK, p38) resulted in marked stabilization of $\beta$-AR mRNA. Budziszewska et al. (2010) observed that chronic treatment with antidepressant drugs attenuated the stress-induced decreased levels of MAPKs in the brain of rats subjected to prenatal stress, but had no effect on its concentration in control animals. Longer half-life may explain the higher levels of $\beta_{1}$-AR mRNA in stressed treated animals, in comparison to placebo group. The results of the mentioned authors can explain the different gene expression of these receptors in normal and stressed conditions. Norepinephrine-promoted destabilization and stress-induced transcription seem to be underlying factors for the interplay of the two opposing pathways controlling receptor mRNA levels. Further experiments on transcriptional activation and mRNA stability will be required to unravel the complexity of stress- and antidepressant-dependent regulation of beta-adrenoceptor gene expression. In chronically stressed individuals, treated with maprotiline, the increased expression of this 
receptor might be a prerequisite in the development of cardiovascular disease given that it initiates irreversible damage to cardiac tissue.

\section{ACKNOWLEDGMENTS}

This work was supported by the Ministry of Education and Science of the Republic of Serbia, Contract No. 173044.

\section{REFERENCES}

ABDEL-RAZAQ, W.; BATES, T.E.; KENDALL, D.A. The effects of antidepressants on cyclic AMP-response elementdriven gene transcription in a model cell system. Biochem. Pharmacol., v.73, n.12, p.1995-2003, 2007.

ADCOCK, I.M.; STEVENS, D.A.; BARNES, P.J. Interactions of glucocorticoids and beta 2-agonists. Eur. Respir. J., v.9, n.1, p.160-168, 1996.

AHLES, S.; GWIRTSMAN, H.; HALARIS, A.; SHAH, P.; SCHWARCZ, G.; HILL M.A. Comparative cardiac effects of maprotiline and doxepin in elderly depressed patients. $J$. Clin. Psychiatry, v.45, n.11, p.460-465, 1984.

BAHOUTH, S.W.; BEAUCHAMP, M.J.; VU, K.N. Reciprocal regulation of beta(1)-adrenergic receptor gene transcription by $\mathrm{Sp} 1$ and early growth response gene 1: induction of EGR1 inhibits the expression of the beta(1)-adrenergic receptor gene. Mol. Pharmacol., v.61, n.2, p.379-390, 2002.

BRODDE, O.E.; MICHEL M.C. Adrenergic and muscarinic receptors in the human heart. Pharmacol. Rev., v.51, n.4, p.651-690, 1999.

BRUM, P.C.; KOSEK, J.; PATTERSON, A., BERNSTEIN, D.; KOBILKA, B. Abnormal cardiac function associated with sympathetic nervous system hyperactivity in mice. Am. J. Physiol. Heart Circ. Physiol., v.283, n.5, p.18381845, 2002.

BUDZISZEWSKA, B.; SZYMANSKA, M.; LESKIEWICZ, M.; BASTA-KAIM, A.; JAWORSKA-FEIL, L.; KUBERA, M.; JANTAS, D.; LASON, W. The decrease in JNKand p38-MAP kinase activity is accompanied by the enhancement of PP2A phosphate level in the brain of prenatally stressed rats. J. Physiol. Pharmacol., v.61, n.2, p.207-215, 2010.
CARNEY, R.M.; FREEDLAND, K.E.; VEITH, R.C. Depression, the autonomic nervous system, and coronary heart disease. Psychosom. Med., v.67, n.1, p.29-33, 2005.

CASPI, A.; SUGDEN, K.; MOFFITT, T.E.; TAYLOR, A.; CRAIG I.W.; HARRINGTON, H. Influence of life stress on depression: Moderation by a polymorphism in the 5-HTT gene. Science, v.301, n.5631, p.386-389, 2003.

DANGEL, V.; GIRAY, J.; RATGE, D.; WISSER, H. Regulation of beta-adrenoceptor density and mRNA levels in the rat heart cell-line H9c2. Biochem. J., v.317, n.3, p.925-931, 1996.

DEUPREE, J.D.; REED, A.L.; BYLUND, D.B. Differential effects of the tricyclic antidepressant desipramine on the density of adrenergic receptors in juvenile and adult rats. $J$. Pharmacol. Exp. Ther, v.321, n.2, p.770-776, 2007.

DRONJAK, S.; SPASOJEVIC, N.; GAVRILOVIC, L.; VARAGIC, V. Effects of norepinephrine and serotonin reuptake inhibitors on pituitary-adrenocortical and sympatho-adrenomedullar system of adult rats. Neuro Endocrinol. Lett., v.28, n.5, p.614-620, 2007.

DUMAN, R.S.; HENINGER G.R.; NESTLER, E.J. A molecular and cellular theory of depression. Arch. Gen. Psychiatry, v.54, n.7, p.597-606, 1997.

DUNIGAN, C.D.; HOANG, Q.; CURRAN, P.K.; FISHMAN P.H. Complexity of agonist- and cyclic AMP-mediated downregulation of the human beta 1-adrenergic receptor: role of internalization, degradation, and mRNA destabilization. Biochemistry, v.41, n.25, p.8019-8030, 2002.

FRECHILLA, D.; OTANO, A.; DEL RÍO, J. Effect of chronic antidepressant treatment on transcription factor binding activity in rat hippocampus and frontal cortex. Prog. Neuropsychopharmacol. Biol. Psychiatry, v.22, n.5, p.787802, 1998.

GRIPPO, A.J.; BELTZ, T.G.; WEISS, R.M.; JOHNSON, A.K. The effects of chronic fluoxetine treatment on chronic mild stress-induced cardiovascular changes and anhedonia. Biol. Psychiatry., v.59, n.4, p.309-316, 2006.

HEADLEY, V.V.; TANVEER, R.; GREENE, S.M.; ZWEIFACH, A.; PORT, J.D. Reciprocal regulation of beta-adrenergic receptor mRNA stability by mitogen activated protein kinase activation and inhibition. Mol. Cell. Biochem., v.258, n.1-2, p.109-119, 2004. 
HEWER, W.; ROST, W.; GATTAZ, W.F. Cardiovascular effects of fluvoxamine and maprotiline in depressed patients. Eur. Arch. Psychiatry Clin. Neurosci., v.246, n.1, p.1-6, 1995.

LAKE, C.R.; PICKAR, D.; ZIEGLER, M.G.; LIPPER, S.; SLATER, S.; MURPHY, D.L. High plasma norepinephrine levels in patients with major affective disorder. Am. J. Psychiatry, v.139, n.10, p.1315-1318, 1982.

LENTINI, S.; RAO, M.L.; SCHRODER, R.; LUDERITZ, B.; BAURIEDEL, G. QT prolongation and torsade de pointes tachycardia during therapy with maprotiline. Differential diagnostic and therapeutic aspects. Dtsch. Med. Wochenschr., v.126, n.49, p.1396-1400, 2001.

LIVAK, K.J.; SCHMITTGEN, T.D. Analysis of relative gene expression data using real-time quantitative PCR and the 2(-Delta Delta C(T)) Method. Methods, v.25, n.4, p.402408, 2001.

LOHSE, M.J.; ENGELHARDT, S.; ESCHENHAGEN, T. What is the role of beta-adrenergic signaling in heart failure? Circ. Res., v.93, n.10, p.896-906, 2003.

MAK, J.C.; NISHIKAWA, M.; SHIRASAKI, H.; MIYAYASU, K.; BARNES P.J. Protective effects of a glucocorticoid on downregulation of pulmonary beta2-adrenergic receptors in vivo. J. Clin. Invest., v.96, n.1, p.99-106, 1995.

MALBON, C.C.; HADCOCK J.R. Evidence that glucocorticoid response elements in the 5 '-noncoding region of the hamster beta 2-adrenergic receptor gene are obligate for glucocorticoid regulation of receptor mRNA levels. Biochem. Biophys. Res. Commun., v.154, n.2, p.676-681, 1988.

MAUSBACH, B.T.; DIMSDALE, J.E.; ZIEGLER, M.G.; MILLS, P.J.; ANCOLI-ISRAEL, S.; PATTERSON, T.L.; GRANT, I. Depressive symptoms predict norepinephrine response to a psychological stressor task in Alzheimer's caregivers. Psychosom. Med., v.67, n.4, p.638-642, 2005.

MINEUR, Y.S.; BELZUNG, C.; CRUSIO, W.E. Effects of unpredictable chronic mild stress on anxiety and depressionlike behavior in mice. Behav. Brain Res. v.175, n.1, p.43-50, 2006.
MYSLIVECEK, J.; RICNY, J.; KOLAR, F.; TUCEK, S. The effects of hydrocortisone on rat heart muscarinic and adrenergic alpha 1, beta 1 and beta 2 receptors, propranololresistant binding sites and on some subsequent steps in intracellular signalling. Naunyn Schmiedebergs. Arch. Pharmacol., v.368, n.5, p.366-376, 2003.

PORT, J.D.; HUANG, L.Y.; MALBON, C.C. Beta-adrenergic agonists that down-regulate receptor mRNA up-regulate a M(r) 35,000 protein(s) that selectively binds to betaadrenergic receptor mRNAs. J. Biol. Chem., v.267, n.33, p.24103-24108, 1992.

ROSENBERG, L.B.; WHANG, W.; SHIMBO, D.; SHAH, A.; SHAPIRO, P.A.; DAVIDSON, K.W. Exposure to tricyclic antidepressants is associated with an increased risk of incident CHD events in a population-based study. Int. J. Cardiol., v.145, n.1, p.124-125, 2010.

TATA, L.J.; WEST, J.; SMITH, C.; FARRINGTON, P.; CARD, T.; SMEETH, L.; HUBBARD, R. General population based study of the impact of tricyclic and selective serotonin reuptake inhibitor antidepressants on the risk of acute myocardial infarction. Heart, v.91, n.4, p.465-471, 2005.

THOME, J.; SAKAI, N.; SHIN, K.; STEFFEN, C.; ZHANG, Y.J.; IMPEY, S.; STORM, D.; DUMAN, R.S. cAMP response element-mediated gene transcription is upregulated by chronic antidepressant treatment. J. Neurosci., v.20, n.11, p.4030-4036, 2000.

TSENG, Y.T.; STABILA, J.; MCGONNIGAL, B.; NGUYEN, T.T.; PADBURY, J.F. An inverted cAMP response element mediates the cAMP induction of the ovine beta 1-adrenergic receptor gene. Biochem. Mol. Biol. Int., v.46, n.6, p.11271134,1998

UEYAMA, T.; SENBA, E.; KASAMATSU, K.; HANO, T.; YAMAMOTO, K.; NISHIO, I.; TSURUO, Y.; YOSHIDA, K. Molecular mechanism of emotional stress-induced and catecholamine-induced heart attack. J. Cardiovasc. Pharmacol, v.41, n.1, p.115-118, 2003.

VEITH, R.C.; LEWIS, N.; LINARES, O.A.; BARNES, R.F.; RASKIND, M.A.; VILLACRES, E.C.; MURBURG, M.M.; ASHLEIGH, E.A.; CASTILlO, S.; PESKIND, E.R.; PASCUALY, M.; HALTER, J.B. Sympathetic nervous system activity in major depression. Basal and desipramineinduced alterations in plasma norepinephrine kinetics. Arch. Gen. Psych., v.51, n.5, p.411-422, 1994. 
WALLUKAT, G. The beta-adrenergic receptors. Herz, v.27, n.7, p.683-690, 2002.

WILLNER, P.; MUSCAT, R.; PAPP, M. Chronic mild stressinduced anhedonia: a realistic animal model of depression. Neurosci. Biobehav. Rev., v.16, n.4, p.525-534, 1992.

XIANG, Y.; KOBILKA, B.K. Myocyte adrenoceptor signaling pathways. Science, v.300, n.5625, p.1530-1532, 2003.

XIAO, R.P.; ZHU, W.; ZHENG, M.; CHAKIR, K.; BOND, R.; LAKATTA, E.G.; CHENG, H. Subtype-specific betaadrenoceptor signaling pathways in the heart and their potential clinical implications. Trends Pharmacol. Sci., v.25, n.7, p.358-365, 2004.

YALCIN, I.; AKSU, F.; BODARD, S.; CHALON S.; BELZUNG, C. Antidepressant-like effect of tramadol in the unpredictable chronic mild stress procedure: possible involvement of the norepinephrinergic system. Behav. Pharmacol., v.18, n.7, p.623-631, 2007.
YEHUDA，R.; SIEVER，L.J.; TEICHER，M.H.; LEVENGOOD, R.A.; GERBER, D.K.; SCHMEIDLER, J.; YANG, R.K. Plasma norepinephrine and 3-methoxy4-hydroxyphenylglycol concentrations and severity of depression in combat posttraumatic stress disorder and major depressive disorder. Biol. Psychiatry, v.44, n.1, p.56-63, 1998.

ZUCHNER, H. QT prolongation and torsade de pointestachycardia in therapy with maprotiline. Dtsch. Med. Wochenschr., v.127, n.18, p.983-984, 2002.

Received for publication on $10^{\text {th }}$ May 2012 Accepted for publication on $25^{\text {th }}$ October 2012 